\title{
Does traumatic occlusal forces lead to peri-implant bone loss? A systematic review
}

Martinna Mendonça BERTOLINI(a)

Altair Antoninha DEL BEL CURY(b)

Lucas PIZZOLOTO(c)

Ivan Ronald Huanca ACAPA(c)

Jamil Awad SHIBLI(d)

Dimorvan BORDIN(c)

(a) University of Connecticut, School of Dental

Medicine, Periodontology, Farmington, $C T$, USA.

(b) Universidade Estadual de Campinas - Unicamp, Piracicaba Dental School, Department of Prosthodontics and Periodontology, Piracicaba, SP, Brazil.

(c) Universidade de Guarulhos - UNG, Department of Restorative Dentistry, Guarulhos, SP, Brazil.

(d) Universidade de Guarulhos - UNG, Department of Periodontology and Oral Implantology, Guarulhos, SP, Brazil

Declaration of Interests: The authors certify that they have no commercial or associative interest that represents a conflict of interest in connection with the manuscript.

Corresponding Author:

Dimorvan Bordin

E-mail: dimorvan.bordin@prof.ung.br

hitps://doi.org/10.1590/1807-3107bor-2019.vol33.0069

Submitted: June 9, 2019

Accepted for publication: June 13, 2019

Last revision: June 17, 2019
Abstract: Observational studies have indicated that crestal bone level changes at implants are typically associated with clinical signs of inflammation, but still mechanical overload has been described as possible factor leading to hard-tissue deficiencies at implant sites without mucosal inflammation. The aim of this paper was systematically review the literature regarding the possible effect of traumatic occlusal forces on the peri-implant bone levels. Literature search was conducted using PubMed, Scielo and Lilacs, including the following terms: oral OR dental AND implant\$ AND (load OR overload OR excessive load OR force $\$$ OR bruxism) AND (bone loss OR bone resorption OR implant failure\$). Databases were searched for the past 10 years of publications, including: clinical human studies, either randomized or not, cohort studies, case control studies, case series and animal research. Exclusion criteria were review articles, guidelines and in vitro and in silico (finite element analysis) research, as well as retrospective studies. The PICO questions formulated was: "does traumatic occlusal forces lead to peri-implant bone loss?" The database searches as well as additional hand searching, resulted in 807 potentially relevant titles. After inclusion/exclusion criteria assessment 2 clinical and 4 animal studies were considered relevant to the topic. The included animal studies did not reveal an association between overload and peri-implant bone loss when lower overloads were applied, whereas in the presence of excessive overload it seemed to generate peri-implant bone loss, even in the absence of inflammation. The effect of traumatic occlusal forces in peri-implant bone loss is poorly reported and provides little evidence to support a cause-and-effect relationship in humans, considering the strength of a clinically relevant traumatic occlusal force.

Keywords: Bone Resorption; Alveolar Bone Loss; Peri-Implantitis.

\section{Introduction}

Disagreement about the relationship between 'traumatic occlusal force' and the progression of periodontal disease has been a topic of study since the 1960's, when the first mechanisms were proposed to understand and explain the inflammatory response associated to trauma as a co-destructive factor in chronic periodontal disease. ${ }^{1}$ At that time, classic animal studies by Lindhe and colleagues, using beagle dogs, 
showed that when proper oral hygiene regimen was followed in periodontal treated areas with the presence of traumatic occlusal forces, the healing process occurred even during trauma, suggesting that microbial biofilm was the main causative factor for periodontal disease in teeth and trauma from occlusion was only a co-destructive factor. ${ }^{2}$

Years later monkey studies by Polson et al., ${ }^{3}$ showed no significant reduction for periodontal attachment loss when in the presence of occlusal trauma and periodontal disease, interestingly though the removal of trauma without periodontal treatment did not lead to disease resolution or bone regeneration. Much later, the effect of occlusal discrepancies was a recurrent topic in periodontal scientific community, Harrel and colleagues investigated in a retrospective clinical study, the relationship of occlusal adjustment in the progression of periodontal disease in 89 patients, again stating that untreated occlusal trauma is a catalyst for progression of periodontal disease. ${ }^{4}$

Historically classified as 'occlusal overloading', in order to indicate that these forces surpass the adaptive capacity of the oral tissues, this term was recently reviewed as 'traumatic occlusal force' by the Consensus report on the Classification of Periodontal and Peri-implant Diseases and Conditions, published in 2018. ${ }^{5}$ This new term now refers to any occlusal force that will lead to teeth or periodontal tissues damage, clinically presented as fremitus, tooth mobility, occlusal discrepancies, wear facets, tooth migration, tooth fracture, and discomfort/pain on chewing; radiographically presented, in teeth, as widened periodontal ligament space, root resorption, cemental tera and hypercementosis. Currently there is no evidence that traumatic occlusal forces alone lead to periodontal attachment loss or gingival recession, however it is accepted that traumatic occlusal forces lead to adaptive mobility in teeth with normal support by thickening the periodontal ligament space, and in teeth with reduced support associated to previous periodontitis, these forces can lead to progressive mobility. ${ }^{5}$

Interest on this theme has been recently renewed with the increase of implant dentistry and with that, the Peri-implant mucositis and the Peri-implantitis. Thus, the question was raised again: Does "traumatic occlusal forces" can lead to peri-implantitis or peri implant bone loss?

To answer this question, it is important to understand that currently, according to the American Academy of Periodontology and European Federation of Periodontology on their 2018 Consensus report, ${ }^{6}$ Peri-implantitis is defined as a biofilm-associated pathological condition taking place in tissues that surround dental implants, characterized by inflammation in the peri-implant mucosa and subsequent progressive loss of supporting bone. Clinically, biofilm-associated peri-implantitis sites exhibit signs of inflammation (redness, swelling, bleeding within 30 seconds following probing) and/or suppuration, increased probing depths and/or recession of the mucosal margin in addition to radiographic bone loss, leading to loss of hard and soft tissue at implant sites. The differential diagnosis between peri-implant mucositis and peri-implantitis is related to the alveolar bone loss after the end of bone remodeling process (normally between 0.5 and $2 \mathrm{~mm}$ ) and requires a radiographic evaluation comparing with the baseline after initial healing.

Possible hypothetical mechanisms of why traumatic occlusal forces can lead to peri-implant bone loss are related to the lack of a periodontal ligament on implants, making them less tolerable to non-axial occlusal loads compared to teeth. ${ }^{8}$ Finite element analysis suggested that the occlusal loads are concentrated at the implant marginal bone ${ }^{9}$ and excessive stress can lead to bone resorption depending on bone 'quality'. ${ }^{\prime 10}$ Also, the microdamage theory states that traumatic occlusal forces have been correlated to bone microfractures and consequently resorption during healing process leading to eventual bone loss, as microdamage accumulates it leads to fracture failures. ${ }^{11}$

Recently, researchers ${ }^{12}$ evaluated seven clinical human studies with a minimum of ten implants and their conclusion suggested that occlusal overload was associated with peri-implant marginal bone loss, however, poor oral hygiene was still the key causative factor. Thus, the sole role of traumatic occlusal forces on peri-implant bone loss requires further investigation with reduced bias effect of bacterial infection. 
The potential influence of lateral static load ${ }^{13}$ and traumatic occlusal force ${ }^{14}$ on peri-implantitis has been addressed in animal studies, with increased or decreased of bacterial biofilms. In the study by Gotfredsen et al., ${ }^{13}$ implants with mucositis and experimental peri-implantitis were exposed to a lateral static load by means of expansion screws (the expansion screws in both sides were activated to a distance amounting to $0.6 \mathrm{~mm}$, resulting in a force of $2.6 \mathrm{~kg}$ ). Their results showed that there was no difference in terms of bone level changes between loaded and unloaded implants and lateral load did not induce bone loss at mucositis sites. These findings were later supported by Heitz-Mayfield et al., ${ }^{14}$ using a dog model with crowns on supra-occlusion contact pattern of at least $3 \mathrm{~mm}$ and oblique occlusal planes to ensure premature contacts with opposing teeth in order to create an occlusal load that was expected to exceed that of the normal physiologic range. Results showed that at implant sites with plaque control there was no increase in probing depth or bleeding on probing, when compared to unload (i.e., no crowns) control implants at 8 months.

Recently, Ferrari et al. ${ }^{15}$ used sandblasted acidetched surfaces implants in dogs, using orthodontic expansion devices attached to abutments, then promoting lateral static load (the expansion screw was opened $4.5 \mathrm{~mm}$, resulting in a force of $20 \mathrm{~kg}$ ). The results were compared with normal load (control) and with submerged unloaded implants. Aiming to reduce presence of bacterial biofilm, chlorhexidine $0.12 \%$ cleaning was performed daily for four months before analysis. Results showed that 5 implants (out of 6) from test group were lost. Radiographically, there was a marginal bone loss of $3.68 \mathrm{~mm}$ for the test group, $1.63 \mathrm{~mm}$ for the control group and 0.45 $\mathrm{mm}$ for the unloaded group. Interestingly, the percentage of bone-to-implant contact was $35.52 \%$, for the test group, $63.16 \%$ for the control group and $42.33 \%$ for the unloaded group, showing an increase of contact when loads are applied, but a decrease if lateral excessive static load is applied. These results suggest that excessive stress can lead to bone resorption, whereas magnitudes below the threshold stress can result in bone apposition, however the clinically responsible parameters for the pathway of overload of already integrated implants have not been identified yet. ${ }^{16}$

Piccinini et al., ${ }^{17}$ reported different biologic responses for bone's thresholds and ultimate strength - microstrain $(\mu \varepsilon)$, here also showed in stress $(\mathrm{MPa})$ and unit-load $\left(\mathrm{kg} / \mathrm{mm}^{2}\right)$, related to bone homeostasis $\left(1,000-1,500 \mu \varepsilon, 20 \mathrm{MPa}\right.$ or $\left.2 \mathrm{~kg} / \mathrm{mm}^{2}\right)$, physiologic overload $\left(1,500-3,000 \mu \varepsilon, 60 \mathrm{MPa}\right.$ or $\left.6 \mathrm{~kg} / \mathrm{mm}^{2}\right)$ and pathologic overload (3,000-6,000 $\mu \varepsilon, 120 \mathrm{MPa}$, or $12 \mathrm{~kg} / \mathrm{mm}^{2}$ ) that leads to bone damage and absorption, these values could explain the results obtained by Gotfredsen et al. ${ }^{13}$, and by Ferrari et al. ${ }^{15}$ on lateral static load dog studies showing bone homeostasis and bone loss, respectively.

To the author's knowledge the topic of Periimplantitis due to traumatic occlusal forces remains poorly reported in humans and provides little unbiased evidence to support a cause-and-effect relationship, due to difficulties in experimental designs to reduce the effect of bacterial infection and to standardize the "traumatic occlusal force" itself, since differences in the magnitude, duration, direction, and frequency of the applied occlusal load will most likely result in different outcomes. Moreover, the tolerance threshold of the host bone (animal versus human) is an important factor that can lead to conflicting results. Thus, the aim of this paper is to revise the literature with respect to the effect of traumatic occlusal forces leading to bone loss in clinically well-integrated implants, excluding when possible, the biofilm influence and focusing on peri implant bone loss due to traumatic occlusal forces alone.

\section{Methodology}

This study followed the PRISMA Statement guidelines. $^{18}$

\section{PICO question}

A well-structured question in the PICO format was formulated to direct the literature searching where PICO stand for: P: stable implants (either immediate load or late load), I: overloaded implants, C: control implants and O: marginal bone loss. The PICO question was structured as follows: "does traumatic occlusal forces lead to peri-implant bone loss?" 


\section{Search strategies}

For this review, a literature search was conducted using PubMed, Scielo and Lilacs. A search strategy for the database was performed to find studies that matched the following terms: oral OR dental AND implant\$ AND (load OR overload OR excessive load OR force\$ OR bruxism) AND (bone loss OR bone resorption OR implant failure\$). Databases were searched without language boundaries using the above-mentioned MeSH terms, with the help of Boolean operators (OR, AND) in order to combine searches.

Manual searches based on reference lists of main papers related to this review and bibliographic section of papers found on the first search were also assessed. Additional search using bruxism AND implants was also done on the same databases.

Moreover, online databases providing information about clinical trials in progress were checked (clinicaltrials.gov; www.centerwatch.com/ clinicaltrials; www.clinicalconnection.com).

\section{Inclusion and exclusion criteria}

Databases were searched for the past 10 years of publications, including: clinical human studies, either randomized or not, cohort studies, case control studies, case series and animal research, correlation peri-implant bone loss over time with maximum bite force or in bruxism patients, as well as in overloaded osseointegrated implants in animal models.

Exclusion criteria were review articles, guidelines and in vitro and in silico (finite element analysis) research, as well as retrospective association studies due to the inability to isolate biofilm as the cause for peri-implant bone loss.

\section{Study selection}

The titles and abstracts of all reports identified through the electronic searches were read independently by 2 authors. For studies appearing to meet the inclusion criteria or for which there were insufficient data in the title and abstract to make a clear decision, the full report was obtained. Disagreements were resolved by discussion between the authors and finally articles that presented indicators that matched our interest were then downloaded for full review and potential inclusion in the study.

\section{Results}

\section{Literature search}

The study selection process is summarized in Figure. The search strategy resulted in 1,304 papers, which were cut down to 807 , when the 10 -year publication date criteria was applied (Table 1). When the combinations of terms used in the literature search of different databases resulted in duplicates, they were not accounted as extra papers. Forty-eight extra papers were included after manual search considering bruxism and implants as mesh terms.

Table 2 shows the relevant results, sorted by study design and split into clinical and/or animal studies that were selected for initial screening of titles and abstracts, resulting in 41 papers after exclusion of 766 papers unrelated to traumatic occlusal forces and peri-implant bone loss.

The full text reports of the remaining 41 papers led to immediate the exclusion of 7 review and in silico studies and 19 human retrospective studies. Additional 9 papers, after full text analysis did not meet the inclusion criteria and were also excluded (Figure), leading to final 6 papers for analysis.

Table 1. Potentially relevant titles from the four database searches.

\begin{tabular}{lcc}
\hline Database & Potentially relevant results & Potentially relevant results iln the last 10 years) \\
\hline PubMed & 1,214 & 327 \\
Lilacs & 33 & 29 \\
Scielo & 45 (bruxism AND implants)/ 9 (reference list & 45 (bruxism AND implants) 3 (reference list \\
Hand search (avoiding duplicated papers) & of review papers) & 3 \\
Total & 1,304 & 807 \\
\hline
\end{tabular}



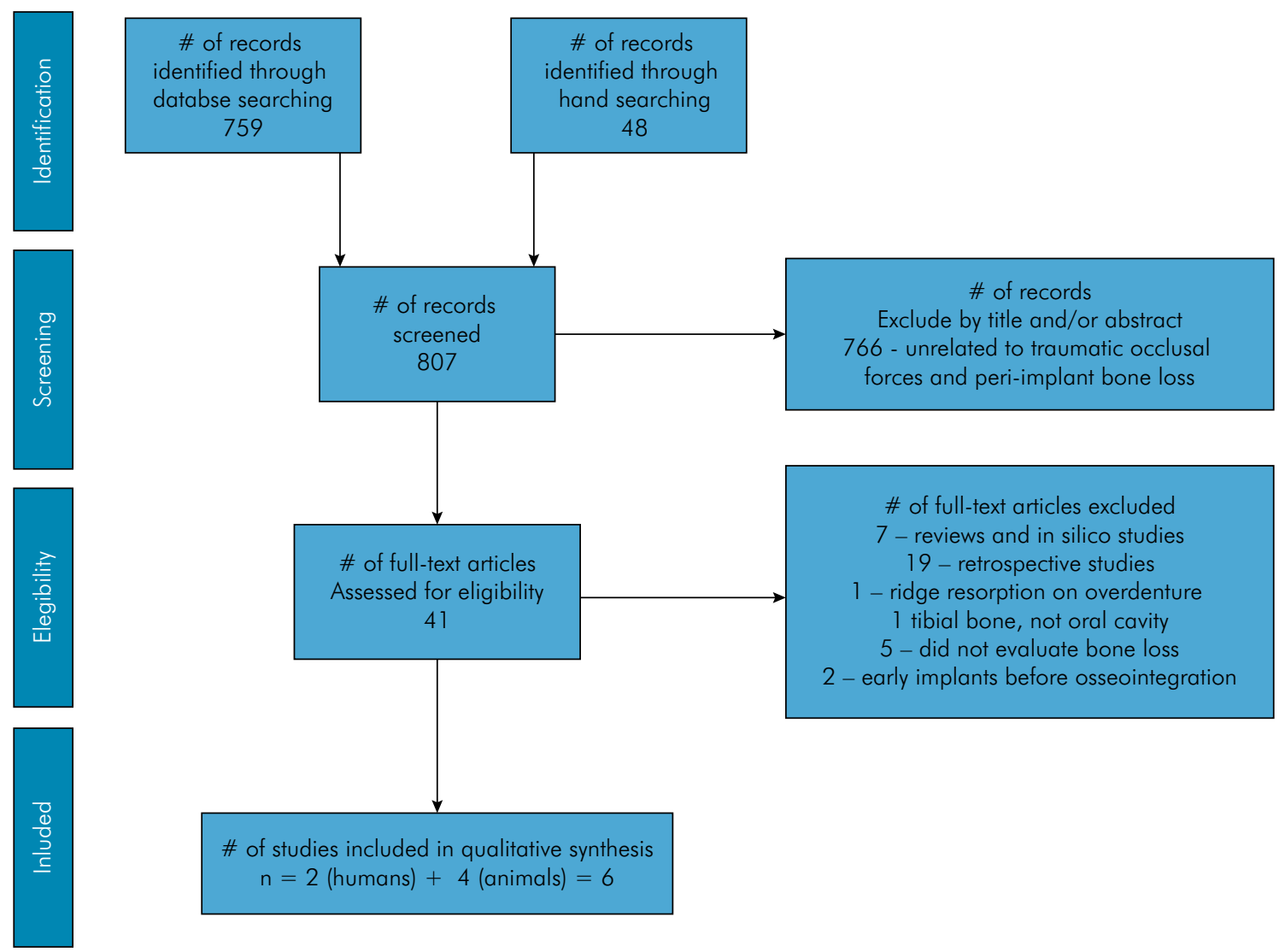

\# of full-text articles excluded

7 - reviews and in silico studies

19 - retrospective studies

1 - ridge resorption on overdenture

1 tibial bone, not oral cavity

5 - did not evaluate bone loss

2 - early implants before osseointegration

Figure. Flow chart of screened, withdrawn and included articles through the review process.

Table 2. Relevant results, sorted by study design and split into clinical and/or animal studies.

\begin{tabular}{lc}
\hline $\begin{array}{l}\text { PubMed, Lilacs, SciELO Databases }+ \\
\text { Hand searching }\end{array}$ & Relevant results \\
\hline Clinical & 1 consort \\
Randomized control trial & 0 \\
Controlled clinical trial & 0 \\
Crossover study & P (4) and R (19) strobe \\
Cohort study (P - prospective or & guide lines \\
R- retrospective) & 0 \\
Case-control studies & 1 \\
Case series/report & 2 \\
Finite element analysis & 5 \\
Reviews & 32 \\
Subtotal & 9 \\
Animal & 41 \\
Total & \\
\hline
\end{tabular}

\section{Description of the studies}

Table 3 shows study characteristics of the clinical study that had to be excluded. This paper by Thymi et al. ${ }^{19}$ was first included in the search as a prospective cohort study evaluating bruxism and peri implant complications, however the authors still have no data published, which made us remove this paper from the current discussion. However, it seems to be a well-designed double-blind, prospective cohort study with a follow-up time of 2 years. The results of this prospective cohort study can provide important information regarding dental implant treatments in bruxing patients. Furthermore, it can generate evidence related to the behavior of dental implants under high mechanical loadings associated to bruxism activity.

Table 4 shows study characteristics of the animal studies included for the review. Podaropoulos et al., ${ }^{20}$ evaluate histologically and histomorphometrically, the peri-implant bone reaction around implants subjected to controlled progressive orthodontic loading. Their 
Table 3. Study characteristics of the clinical studies excluded.

\begin{tabular}{|c|c|c|c|c|c|c|}
\hline Study & Year & Method & $\begin{array}{l}\text { Patients/Implants/ } \\
\text { loading method/ } \\
\text { follow up time }\end{array}$ & Type of intervention & Outcome & Reason for exclusion \\
\hline Thymi et al. ${ }^{19}$ & 2017 & $\begin{array}{l}\text { Single-center, } \\
\text { double-blind, } \\
\text { prospective } \\
\text { cohort study }\end{array}$ & $\begin{array}{l}98 \text { patients with sleep } \\
\text { bruxism/ implant } \\
\text { supported fixed } \\
\text { prosthesis/ } 2 \text { years } \\
\text { follow up }\end{array}$ & $\begin{array}{l}\text { One or more implants } \\
\text { for replacement of one } \\
\text { or more lost teeth }\end{array}$ & $\begin{array}{c}\text { Biological } \\
\text { complications (i.e., } \\
\text { related to peri-implant } \\
\text { bleeding, probing } \\
\text { depth, marginal } \\
\text { bone height, quality } \\
\text { of submucosal } \\
\text { biofilm and loss of } \\
\text { osseointegration) }\end{array}$ & $\begin{array}{l}\text { The study is currently } \\
\text { ongoing, and data } \\
\text { are being gathered. }\end{array}$ \\
\hline
\end{tabular}

Table 4. Study characteristics and quality assessment of the animal studies included for the review.

\begin{tabular}{|c|c|c|c|c|c|c|}
\hline Study & Year & Method & $\begin{array}{l}\text { Animals/Implants/ } \\
\text { loading method/ } \\
\text { follow up time }\end{array}$ & $\begin{array}{c}\text { Type of intervention } \\
\text { and load }\end{array}$ & Microbial control & Outcome \\
\hline Ferrari et al., ${ }^{15}$ & 2015 & $\begin{array}{l}\text { Dog } \\
\text { study }\end{array}$ & $\begin{array}{l}7 \text { mongrel dogs, } \\
42 \text { implants; } 20 \mathrm{kgs} \\
\text { load immediately } \\
\text { implant placement, } \\
4 \text { months } \\
\text { evaluation period. }\end{array}$ & $\begin{array}{l}2 \text { control groups: (1) } \\
\text { None device was used. } \\
\text { (2) Orthodontic device, } \\
\text { no loading activation; } \\
\text { (3)- experimental group: } \\
\text { orthodontic device } \\
\text { (4.5mm of lateral } \\
\text { expansion) device. No } \\
\text { occlusal interference was } \\
\text { carried out. Bone-to- } \\
\text { implant contact (BIC) and } \\
\text { radiographic analysis. }\end{array}$ & $\begin{array}{l}\text { During the } \\
\text { healing } \\
\text { period. } 0.12 \% \\
\text { chlorhexidine } \\
\text { daily. }\end{array}$ & $\begin{array}{l}\text { The experimental group } \\
\text { showed lower BIC (35.52\%) } \\
\text { than controls. No difference } \\
\text { between controls (none device } \\
42.33 \% \text {; device without } \\
\text { activation } 63.18 \%) \text {. Test } \\
\text { groups showed radiographic } \\
\text { bone loss ( } 3.68 \mathrm{~mm} \text { ) almost } \\
\text { three times higher than } \\
\text { control group }(1.63 \mathrm{~mm}) ; \\
\text { unloaded group }(0.45 \mathrm{~mm}) \text {. }\end{array}$ \\
\hline Podaropoulos et al. ${ }^{20}$ & 2016 & $\begin{array}{l}\text { Dog } \\
\text { study }\end{array}$ & $\begin{array}{l}3 \text { Beagle dogs, } \\
24 \text { implants; } \\
\text { progressive loading } \\
\text { started } 8 \text { weeks } \\
\text { after implant } \\
\text { placement (100, } \\
\text { 200, 300g) vs. } \\
\text { unloading, } \\
9 \text { weeks. }\end{array}$ & $\begin{array}{c}\text { progressive loading } \\
\text { (orthodontic device). } \\
\text { Bone-to-implant contact, } \\
\text { bone density measured } 1 \\
\text { and } 2 \text { mm distant of the } \\
\text { implant. }\end{array}$ & $\begin{array}{l}\text { The abutments } \\
\text { were brushed } \\
\text { three times per } \\
\text { week }(0.2 \% \\
\text { chlorhexidine } \\
\text { digluconate } \\
\text { solution). }\end{array}$ & $\begin{array}{l}\text { Progressive loading showed } \\
\text { higher bone-to-implant } \\
\text { contact than unloaded. } \\
\text { No difference of } 1 \text { and } \\
2 \mathrm{~mm} \text { distant of implants } \\
\text { for both groups. Crestal } \\
\text { bone resorption was similar } \\
\text { between groups. }\end{array}$ \\
\hline Nagasawa et al. ${ }^{21}$ & 2013 & $\begin{array}{l}\text { Rat } \\
\text { study }\end{array}$ & $\begin{array}{l}40 \text { rats received } \\
4 \text { implants each. } \\
\text { After } 2 \text { weeks } \\
\text { (early) or } 4 \text { weeks } \\
\text { (late load) implants } \\
\text { were loaded. } \\
\text { Follow up after } 5 \text {, } \\
10 \text { and } 15 \text { days. }\end{array}$ & $\begin{array}{l}\text { Test group received } \\
\text { abutments with distal } \\
\text { cantilevers designed to } \\
\text { overload and control } \\
\text { group implants did not } \\
\text { receive abutments. }\end{array}$ & None & $\begin{array}{l}\text { Focused on early placed } \\
\text { implants, which are not fully } \\
\text { integrated. After } 15 \text { days of } \\
\text { overload, all } 2 \text { week implants } \\
\text { were loss and } 4 \text { week } \\
\text { implants showed areas of } \\
\text { bone resorption }\end{array}$ \\
\hline Miyamoto et al. ${ }^{22}$ & 2008 & $\begin{array}{l}\text { Dog } \\
\text { study }\end{array}$ & $\begin{array}{l}12 \text { male beagles, } \\
\text { received } 6 \text { implants } \\
\text { each, implants } \\
\text { loaded } 12 \text { weeks } \\
\text { after implant } \\
\text { placement } \\
\text { (12 weeks follow } \\
\text { up load) or } 20 \\
\text { weeks after implant } \\
\text { placement (4-weeks } \\
\text { follow up load) }\end{array}$ & $\begin{array}{l}\text { Each distal implant } \\
\text { received a cantilever } \\
\text { structure to the mesial, } \\
\text { which was forced down } \\
\text { by a controlled static } \\
\text { overload by using a } 250 \\
\mu \mathrm{m} \text { movement on a screw } \\
\text { over a platform, retained } \\
\text { on both remaining } \\
\text { implants }\end{array}$ & $\begin{array}{l}\text { Soft tissue and } \\
\text { residual teeth } \\
\text { were brushed } 3 \\
\text { times a week }\end{array}$ & $\begin{array}{l}\text { Marginal bone loss was } \\
\text { significantly greater in the } \\
12 \text {-week ( } 2.55 \mathrm{~mm}) \text { loaded } \\
\text { implants when compared to } \\
\text { 4-week loaded }(1.48 \mathrm{~mm}) \\
\text { and unloaded }(1.10 \mathrm{~mm}) \\
\text { implants }\end{array}$ \\
\hline
\end{tabular}


model used beagle dogs that received implants in posterior mandible. Loading was done after 8 weeks of healing, using abutments connected by pairs with $\mathrm{Ni}-\mathrm{Ti}$ orthodontic springs by which a gradual static force of 100, 200 and $300 \mathrm{~g}$ was applied for a 3-week period each, resulting in a total progressive loading period of 9 weeks. Unloaded control implants were used as comparison. Implants of the progressive loading group exhibited significantly higher percentage of bone-to-implant contact compared to the unloaded control implants. Crestal bone resorption did not differ between loaded and unloaded implants.

On the other hand, Ferrari et al., ${ }^{15}$ showed the effect of lateral static load on posterior implants placed on mongrel dogs. Loading was done immediately after implants with an orthodontic expansion device that promoted lateral excessive static load (test group). Normal load (control) submerged implants (unloaded group) were used for comparison. Devices were cleaned daily with chlorhexidine $0.12 \%$, during the 4 months of study. Five implants from test group were lost in 3 dogs. Radiographically, there was a marginal bone loss of $3.68 \mathrm{~mm}$ for the test group, 1.63 for the control group and $0.45 \mathrm{~mm}$ for the unloaded group. Author's concluded that the excessive lateral static load negatively affected the behavior of periimplant bone around immediate restored implants.

Corroborating these results Nagasawa et al., ${ }^{21}$ histologically assessed degenerative changes under early and excessive occlusal loading. They used a rat model in which machined surface implants were placed in posterior mandible. Loading was done after 2 or 4 weeks and control implants remained unloaded. Specimens showed remarkable bone loss and deterioration of osseointegration when overloading began at 2 weeks. Overloading applied after 4 weeks of healing induced active bone resorption. This model revealed degenerative changes in osseointegration and/or in the bone around implants upon excessive occlusal loading, emphasizing the risks associated with immediate loading and overloading. No microbiological control was done in this study to avoid bacterial plaque accumulation around implants.

Regarding late implant loading studies, Miyamoto et al., ${ }^{22}$ aimed to investigate bony changes around selectively overloaded implants in dogs after 12 and 20 weeks following implant placement. Each dog received 3 implants and each distal implant received a cantilever-type superstructure extending in a mesial direction so as to be able to receive a controlled overload coming from the mesial and central implants superstructures. The force was induced by a controlled static $250 \mu \mathrm{m}$ screw fixed on mesial and central implants, exerting an apical force on the mesial cantilever of distal implant. After 24 weeks, tissue specimens including implants were evaluated histologically and histomorphometrically. Marginal bone loss was significantly greater in the 12-week-load group than in the 4-week-load group. These findings demonstrate that static overload-induced forces can elicit changes in peri-implant bone in experimental animals. However, it is important to highlight that no oral hygiene procedure was performed on these animals.

Table 5 shows the only human study included in this review. Jofré et al, 2010 aimed to evaluate the effect of maximum physiological bite force on

Table 5. Study characteristics and quality assessment of the human studies included for the review.

\begin{tabular}{|c|c|c|c|c|c|c|}
\hline Study & Year & Method & $\begin{array}{l}\text { Patients/Implants/ } \\
\text { loading method/ } \\
\text { follow up time }\end{array}$ & $\begin{array}{c}\text { Type of intervention } \\
\text { and load }\end{array}$ & Microbial control & Outcome \\
\hline Jofre et al. ${ }^{23}$ & 2010 & $\begin{array}{l}\text { Randomized } \\
\text { controlled } \\
\text { clinical trial }\end{array}$ & $\begin{array}{c}45 \text { edentulous patients } \\
\text { received } 2 \text { implants } \\
\text { each, on mandibular } \\
\text { anterior area. Follow } \\
\text { up was } 5,7,10 \text { and } \\
15 \text { months }\end{array}$ & $\begin{array}{l}23 \text { patients received } \\
\text { bar overdentures and } \\
22 \text { ball attachment } \\
\text { overdentures. Marginal } \\
\text { bone loss was verified } \\
\text { by standardized x-rays } \\
\text { and maximum bite } \\
\text { force was recorded. }\end{array}$ & $\begin{array}{l}\text { All patients received } \\
\text { post-operative } \\
\text { implant care } \\
\text { instructions. }\end{array}$ & $\begin{array}{l}\text { Marginal bone loss } \\
\text { around implants was not } \\
\text { related to the maximal } \\
\text { bite force in patients } \\
\text { wearing overdentures } \\
\text { retained by bar or ball } \\
\text { attachment system }\end{array}$ \\
\hline
\end{tabular}


marginal bone loss around implants in edentulous patients wearing mandibular overdentures with ball and bar retention systems. ${ }^{23} \mathrm{~A}$ single randomization was performed to allocate the patients in two groups and the maximum bite force was recorded to be associated with marginal bone loss using standardized radiographs at the baseline and 5, 7, 10, and 15 months after surgery. No relationship was found between maximum bite force and marginal bone loss for patients wearing overdentures using bar or ball attachment systems. Even though authors call it maximum bite force, the measurement was with full dentures, which can underestimate the maximum bite force of a fully dentated patient in parafunctional habit such as bruxism.

\section{Discussion}

In the past decade, investigators have studied the role of occlusal overload in osseointegrated implants in animal $1^{15,20,21,22}$ and human studies ${ }^{23}$ with contradictory findings. These inconsistent results might be due to the different methodologies used to apply forces, that can be occlusal or lateral static forces with many variations for load, duration, healing time before loading and the biofilm control method. Unfortunately, in the last 10 years of published papers the PICO question remains unanswered: "does traumatic occlusal forces lead to peri-implant bone loss?"

Our search on clinical studies focusing on the potential effect of overload on peri-implant bone loss resulted in only 1 randomized controlled clinical trial. ${ }^{23}$ Even though this is a high higher hierarchical study design the load magnitude was defined at the prosthesis level, in fully edentulous patients which could hardly represent the same overload as a fully dentated patient, defined by an occlusal force that will lead to teeth or periodontal tissues damage. Therefore, the lack of reliable clinical and scientific evidence concerning the influence of traumatic occlusal forces in dental implants may be related to the difficulty in precisely quantifying the magnitude and direction of forces in clinical studies, as well as how to standardize the forces and define what is considered "traumatic occlusal forces" and how to evaluate those in the clinical studies, since the opportunity to test such an intentional and standardized "traumatic occlusal force" in humans remains inappropriate and unethical.

Animal models, however, has this potential and several methodologies with external loading devices, such as the ones mentioned above have been used in order to stablish well-controlled and well-defined loads in order to explore the peri-implant bone loss to mechanical loads. Nevertheless, it is still impossible to measure the exact strains the peri-implant tissues are exposed to and correlate this with the human responses. From the above-mentioned papers it seems that different forces, e.g., 300 grams $^{20}$ versus $20 \mathrm{~kg}^{15}$ will generate opposite results, such as higher bone-to-implant contact than unloaded implants versus radiographic bone loss almost three times higher than unloaded control implants. These results could be explained by the healing/ adaptation theory, proposed by Chvartsaid et al. ${ }^{24}$ to explain peri-implant bone loss. They claim that marginal bone loss and implant failure depend on similar mechanisms, with the magnitude of the trauma determining whether an implant may fail or/and will result in marginal bone loss. The healing/adaptation theory sees adverse loading or peri-implantitis to be, at best, part of the problem behind marginal bone loss.

However, it is important to highlight that mechanical overload can be categorized into two different entities: loading forces preventing the implant to osseointegrate during the healing phase, and loading forces destroying a previously established osseointegration. Among our animal studies, some evaluate overload immediately after implant placement, ${ }^{15} 2$ to 4 weeks after implant placement, ${ }^{21} 8$ weeks after implant placement ${ }^{20}$ and 12 weeks after implant placement (12 weeks follow up load ) or 20 weeks after implant placement (4-weeks follow up load) ${ }^{22}$, therefore a comparison among the studies is unlikely. The absence of micromotion is not a prerequisite for successful osseointegration. It has been shown that during the phase of bone integration of an implant micromotions of less than $50 \mu \mathrm{m}$ to $150 \mu \mathrm{m}$ are still amendable to successful bone integration. ${ }^{25}$ Considering these values, it was expected to see bone loss on Miyamoto et al, in which 
each distal implant received a cantilever structure to the mesial, which was forced down by a controlled static overload by using a $250 \mu \mathrm{m}$ movement on a screw over a platform, retained on both remaining implants. ${ }^{22}$ However it is important to highlight that there was no bacterial plaque prevention/removal around implants on this study, which, even though bacterial rat microbiome is different than human, it could have some influence in the outcome of bone loss.

Also, it has been reported in the literature that excessive strain can lead to bone resorption, whereas magnitudes below this strain result in bone apposition, which would be in agreement with Podaropoulos et al., ${ }^{20}$ which used 300 grams and Ferrari et al., ${ }^{15}$ which used $20 \mathrm{~kg}$. However, the clinically responsible parameters for the pathway of overload of already integrated implants have not been identified thus far. ${ }^{26}$

According to Wennerberg and Albrektsson ${ }^{28}$ if ongoing marginal bone loss does occur, implant micro movements may succeed and that will be associated to secondary peri-implantitis. This secondary problem may, of course, need clinical treatment. This theory is much more generally applicable to the true clinical situation than are hypotheses of isolated peri-implantitis or overloading. A number of additional factors have been associated with periimplantitis in case reports, finite-element analyses or pre-clinical research (e.g. bone compression necrosis, over-heating, micromotion, and biocorrosion). The importance of such factors should be evaluated in future research.

It seems that the evidence for overload of osseointegrated implants leading to hard and/or soft tissue defects is very scarce. ${ }^{16}$ Our review found that there is a complete lack of well-structured studies testing overload in a clinical environment and more precise parameters should be stablished to allow comparison among different human or animal studies.

To the author's knowledge there is evidence from observational studies that patients exhibiting poor plaque control and not attending regular maintenance therapy are at higher risk of developing peri-implantitis, but overload alone, as cause for bone loss in humans remains unclear. Studies on treatment of peri-implantitis reveal that anti-infective treatment strategies are successful in decreasing soft tissue inflammation and in suppressing disease progression. ${ }^{6}$ Moreover evidence from a 10 -year prospective study suggests that progressive crestal bone loss around implants in the absence of clinical signs of soft tissue inflammation is a rare event. ${ }^{28}$

Regarding risk factors for peri-implantitis, there is some limited evidence in the literature linking peri-implantitis to factors such as post-restorative presence of submucosal cement and positioning of implants that does not facilitate oral hygiene and maintenance and the role of peri-implant keratinized mucosa, occlusal overload, titanium particles, bone compression necrosis, overheating, micromotion and biocorrosion as risk indicators for peri-implantitis remains to be determined. ${ }^{6}$

This systematic review was restricted to studies published in English which may have introduced language bias. However, given that the studies considered in this review emanate from many countries where English is not the first language, we may not have missed too many significant reports. Furthermore, hand searching of popular implant journals may have identified additional studies for this review.

\section{Conclusion}

Clinical and animal models of treatment interventions of oral implants designed to study overload and published from 2008 to 2018 are nearly lacking. Based on the animal models reported here, current literature suggests that there might be an association between occlusal overloading and peri-implant bone loss when pathologic overload is applied prior osseointegration (> $12 \mathrm{~kg} / \mathrm{mm}^{2}$ ) leading to bone damage and absorption, in the absence of inflammation. However, when bone homeostasis loads $\left(<2 \mathrm{~kg} / \mathrm{mm}^{2}\right)$ are applied after osseointegration, that leads to higher bone-to-implant contact and no crestal bone resorption, in the absence of inflammation. These data should be interpreted with caution, as they come from dog models and they highlight the need for human evidence on this topic, since results are still controversial. The effect of traumatic forces in peri-implant bone loss is poorly reported and provides limited evidence to support a 
cause-and-effect relationship in humans considering the strength of a clinically relevant traumatic occlusal force. There is a high priority to conduct studies that are designed to develop diagnostic, preventive, and intervention strategies for the management of these peri-implant issues.

\section{References}

1. Glickman I. Inflammation and trauma from occlusion, co-destructive factors in chronic periodontal disease. J Periodontol. 1963;34(1):5-10. https://doi.org/10.1902/jop.1963.34.1.5

2. Lindhe J, Ericsson I. The influence of trauma from occlusion on reduced but healthy periodontal tissues in dogs. J Clin Periodontol. 1976 May;3(2):110-22. https://doi.org/10.1111/j.1600-051X.1976.tb01857.x

3. Polson AM, Zander HA. Effect of periodontal trauma upon intrabony pockets. J Periodontol. 1983 Oct;54(10):586-91. https://doi.org/10.1902/jop.1983.54.10.586

4. Harrel SK, Nunn ME. The effect of occlusal discrepancies on periodontitis. II. Relationship of occlusal treatment to the progression of periodontal disease. J Periodontol. 2001 Apr;72(4):495-505. https://doi.org/10.1902/jop.2001.72.4.495

5. Jepsen S, Caton JG, Albandar JM, Bissada NF, Bouchard P, Cortellini P, et al. Periodontal manifestations of systemic diseases and developmental and acquired conditions: Consensus report of workgroup 3 of the 2017 World Workshop on the Classification of Periodontal and Peri-Implant Diseases and Conditions. J Periodontol. 2018 Jun;89 Suppl 1:S237-48. https://doi.org/10.1002/JPER.17-0733

6. Berglundh T, Armitage G, Araujo MG, Avila-Ortiz G, Blanco J, Camargo PM, et al. Peri-implant diseases and conditions: Consensus report of workgroup 4 of the 2017 World Workshop on the Classification of Periodontal and Peri-Implant Diseases and Conditions. J Periodontol. 2018 Jun;89 Suppl 1:S313-8. https://doi.org/10.1002/JPER.17-0739

7. Renvert S, Persson GR, Pirih FQ, Camargo PM. Peri-implant health, peri-implant mucositis, and peri-implantitis: case definitions and diagnostic considerations. J Clin Periodontol. 2018 Jun;45 Suppl 20:S278-85. https://doi.org/10.1111/jcpe.12956

8. Kim Y, Oh TJ, Misch CE, Wang HL. Occlusal considerations in implant therapy: clinical guidelines with biomechanical rationale [Review]. Clin Oral Implants Res. 2005 Feb;16(1):26-35. https://doi.org/10.1111/j.1600-0501.2004.01067.x

9. Rungsiyakull C, Rungsiyakull P, Li Q, Li W, Swain M. Effects of occlusal inclination and loading on mandibular bone remodeling: a finite element study. Int J Oral Maxillofac Implants. 2011 May-Jun;26(3):527-37.

10. Crupi V, Guglielmino E, La Rosa G, Vander Sloten J, Van Oosterwyck H. Numerical analysis of bone adaptation around an oral implant due to overload stress. Proc Inst Mech Eng H. 2004;218(6):407-15. https://doi.org/10.1243/0954411042632171

11. Lee TC, O'Brien FJ, Gunnlaugsson T, Parkesh R, Taylor D. Microdamage and bone mechanobiology. Technol Health Care. 2006;14(4-5):359-65.

12. Fu JH, Hsu YT, Wang HL. Identifying occlusal overload and how to deal with it to avoid marginal bone loss around implants. Eur J Oral Implantol. 2012;5 Suppl:S91-103.

13. Gotfredsen K, Berglundh T, Lindhe J. Bone reactions at implants subjected to experimental peri-implantitis and static load: a study in the dog. J Clin Periodontol. 2002 Feb;29(2):144-51. https://doi.org/10.1034/i.1600-051x.2002.290209.x

14. Heitz-Mayfield LJ, Schmid B, Weigel C, Gerber S, Bosshardt DD, Jönsson J, et al. Does excessive occlusal load affect osseointegration? An experimental study in the dog. Clin Oral Implants Res. 2004 Jun;15(3):259-68. https://doi.org/10.1111/j.1600-0501.2004.01019.x

15. Ferrari DS, Piattelli A, lezzi G, Faveri M, Rodrigues JA, Shibli JA. Effect of lateral static load on immediately restored implants: histologic and radiographic evaluation in dogs. Clin Oral Implants Res. 2015 Apr;26(4):e51-6. https://doi.org/10.1111/clr.12331

16. Hämmerle CH, Tarnow D. The etiology of hard- and soft-tissue deficiencies at dental implants: A narrative review. J Periodontol. 2018 Jun;89 Suppl 1:S291-303. https://doi.org/10.1002/JPER.16-0810

17. Piccinini M, Cugnoni J, Botsis J, Ammann P, Wiskott A. Numerical prediction of peri-implant bone adaptation: comparison of mechanical stimuli and sensitivity to modeling parameters. Med Eng Phys. 2016 Nov;38(11):1348-59. https://doi.org/10.1016/i.medengphy.2016.08.008

18. Moher D, Liberati A, Tetzlaff J, Altman DG. Preferred reporting items for systematic reviews and meta-analyses: the PRISMA statement. Ann Intern Med. 2009 Aug 18;151(4):264-9. https://doi.org/10.1371/journal.pmed.1000097

19. Thymi M, Visscher CM, Yoshida-Kohno E, Crielaard W, Wismeijer D, Lobbezoo F. Associations between sleep bruxism and (peri-) implant complications: a prospective cohort study. BDJ Open. 2017 Apr 14;3:17003. https://doi.org/10.1038/bdjopen.2017.3. eCollection 2017.

20. Podaropoulos L, Veis AA, Trisi P, Papadimitriou S, Alexandridis C, Kalyvas D. Bone reactions around dental implants subjected to progressive static load: an experimental study in dogs. Clin Oral Implants Res. 2016 Jul;27(7):910-7. https://doi.org/10.1111/clr.12658 
21. Nagasawa M, Takano R, Maeda T, Uoshima K. Observation of the bone surrounding an overloaded implant in a novel rat model. Int J Oral Maxillofac Implants. 2013 Jan-Feb;28(1):109-16. https://doi.org/10.11607/jomi.2388

22. Miyamoto Y, Koretake K, Hirata M, Kubo T, Akagawa Y. Influence of static overload on the bony interface around implants in dogs. Int J Prosthodont. 2008 Sep-Oct;21(5):437-44.

23. Jofré J, Hamada T, Nishimura M, Klattenhoff $C$. The effect of maximum bite force on marginal bone loss of mini-implants supporting a mandibular overdenture: a randomized controlled trial. Clin Oral Implants Res. 2010 Feb;21 (2):243-9. https://doi.org/10.1111/i.1600-0501.2009.01834.x

24. Chvartsaid D, Koka S, Zarb G. Osseointegration failure. In: Zarb G, Albrektsson T, Baker G, Eckert SE, Satnford C, Tarnow DP, editors. Osseointegration: on continuing synergies in surgery, prosthodontics, biomaterials. Chicago (IL): Quintessence; 2008 . p. 157-64.

25. Szmukler-Moncler S, Salama H, Reingewirtz Y, Dubruille JH. Timing of loading and effect of micromotion on bone-dental implant interface: review of experimental literature. J Biomed Mater Res. 1998;43(2):192-203. https://doi.org/10.1002/(SICI)1097-4636(199822)43:2<192::AID-JBM14>3.0.CO;2-K

26. Chambrone L, Chambrone LA, Lima LA. Effects of occlusal overload on peri-implant tissue health: a systematic review of animal-model studies. J Periodontol. 2010 Oct;81(10):1367-78. https://doi.org/10.1902/jop.2010.100176

27. Wennerberg A, Albrektsson T. Current challenges in successful rehabilitation with oral implants. J Oral Rehabil. 2011 Apr;38(4):286-94. https://doi.org/10.1111/j.1365-2842.2010.02170.x

28. Cecchinato D, Parpaiola A, Lindhe J. Mucosal inflammation and incidence of crestal bone loss among implant patients: a 10-year study. Clin Oral Implants Res. 2014 Jul;25(7):791-6. https://doi.org/10.1111/clr.12209 